
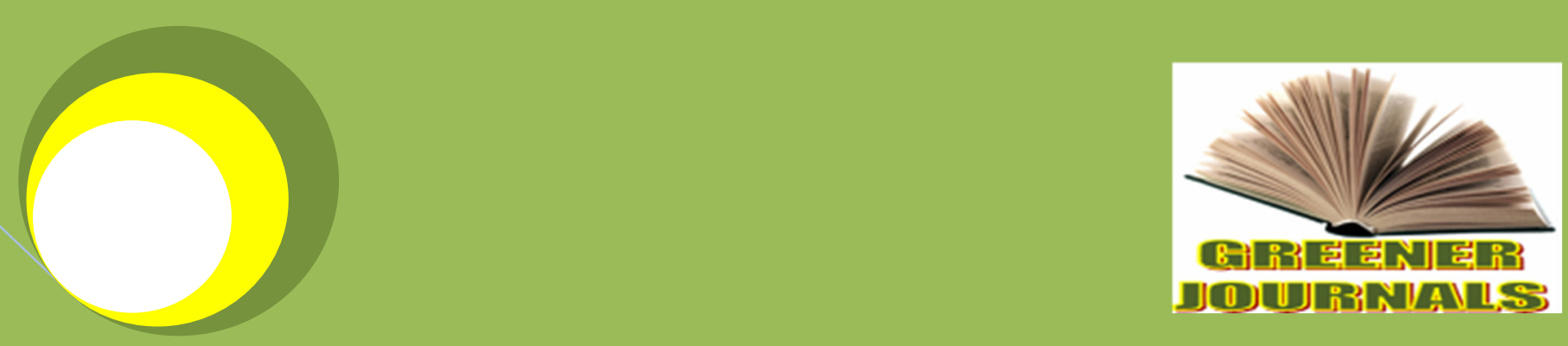

Greener.Journal of Social Sciences ISSN: 2276-7800 ICV: 5.99

Submitted: 09/01/2017 Accepted: 27/01/2017 Published: 01/03/2017

\title{
Assessment of \\ Opportunities and Constraints of Small Ruminant Production and Marketing in Tahtay Adyabo District, Tigray, Ethiopia
} By Zemeda Desta 


\title{
Assessment of Opportunities and Constraints of Small Ruminant Production and Marketing in Tahtay Adyabo District, Tigray, Ethiopia
}

\section{Zemeda Desta}

\author{
Tigray Agricultural Research Institute (TARI) Shire -Maitsebri Agricultural Research Center, P.O.Box 81, Shire, \\ Ethiopia. \\ E-mail: zemedadesta @gmail.com
}

\begin{abstract}
This study was aimed at assessment of opportunities and constraints of small ruminant production and marketing in TahtayAdyabo District of Tigray. The data were collected fromboth primary and secondary sources. Primary data were collected from a randomly selected 138 sample households and 26 traders. The study showed that constraints hindering the development of small ruminant production were animal diseases $(58.7 \%)$, inadequate animal health services (13\%) shortage of feed $(10.9 \%)$, shortage of land $(9.4 \%)$, shortage of labor $(5.1 \%)$ and predators $(2.9 \%)$. On the marketing side, lack of livestock market information $(57.98 \%)$, seasonality of small ruminant demand $(29.71 \%)$, distance to livestock market $(10.14 \%)$ and low market price for small ruminant $(2.17 \%)$ are the major marketing problems of small ruminant producers. Unlicensed traders $(61.5 \%)$, seasonality of supply $(27 \%)$ and problem in information flow (11.5\%) are the major marketing problems mentioned by traders. Therefore, provision of adequate veterinary services and drugs,developing and improving infrastructure, creation of awareness to farmers about improved forage species and supplementary feeding, provision of timely and accurate market information and enforced government rules and regulations on business registration and licensing are important interventions.
\end{abstract}

Keywords: Marketing, Production, Small ruminant, TahtayAdyabo District, Ethiopia.

\section{INTRODUCTION}

Ethiopia is endowed with huge livestock resources, natural resources and diverse agro-ecological zones suitable for livestock production. These potentials make the country prominent repository for animal genetic diversity[9]. Livestock production plays an important role to smallholder farmers and the national economy of the country. It contributes 15 to17 percent of GDP and 35 to 49 percent of agricultural GDP and 37 to 87 percent of the household income [5].

Ethiopia has 29.33 and 29.11 million sheep and goats population respectively. From the total small ruminant population, $99.8 \%$ of the sheep and nearly all goat population of the country are local breeds [2]. They are important components of the livestock sub-sector and sources of cash income; meat, milk, wool, manure and saving or risk distribution for smallholders in different farming systems and agro-ecological zones of the country [14,4 and 7]. Small ruminants are also sources of foreign currency [6]. Moreover, due to their high fertility, short generation interval, adaptation in harsh environment and their ability to produce in limited feed resource, they are considered as investment and insurance [15].The levels of foreign exchange earnings from livestock and livestock products are much lower than would be expected, given the size of the livestock population. A number of fundamental constraints underlie these outcomes, including inadequate veterinary services, feed shortages, poor infrastructure, insufficient financial services and low levels oftechnical inputs [6,8].

Demand for Ethiopian sheep and goat meat has dramatically increased after market promotion by development projects in close collaboration with the government. There is a general increase in demand for sheep and goat meat both in the domestic and export markets. This has created an opportunity for sheep and goat producers to sell more animals at better prices. The increase in international demand for meat in general and the high demand for sheep and goat meat in the Middle East are another incentive for sheep and goat production in the country. However, the supply of small ruminant to both markets is not well strategized as production is not marketoriented. Moreover, there is no livestock market information system that informs farmers which animals are needed, who are the potential buyers, and prices for the different class of animals. Developing efficient input delivery systems, 
knowledge-based animal husbandry (including feeding, breeding, housing and health care), cost-effective marketing, and efficient and equitable supply chains are important interventions [10].

Tigray region has suitable agro-ecology for small ruminant production. There are about 4.2 and 1.8 million goats and sheep population respectively in the region [2]. Small ruminant production has significant contribution for household income, as source of food (meat and milk) and manure in the region. TahtayAdyabo District is one of the potential areas for small ruminant production and marketing. Moreover, Begait breeds of small ruminant which are utilized both for meat and milk production belongs to this district [13]. TahtayAdyabo District has 158,418 goat and 32,433 sheep population [11]. Different actors are participating along the market of small ruminant in the district. Even though, the study area is the center of production of small ruminant and have access to domestic markets, research regarding opportunities and constraints of small ruminant production and marketing has not been conducted which can guide stakeholders to be able to use the potential of the resource optimally. Problems in small ruminant production and marketing hinder the potential gains that could have been attained from the existing opportunities. In this regard, assessment of opportunities and constraints of small ruminant production and marketing is an important study that has not been investigated in TahtayAdyabo District of Tigray region.

\section{MATERIALS AND METHODS}

\section{Study area}

TahtayAdyabo District is one of the eight districts found in north western Zone of Tigray Regional State. The district is composed of 17 rural kebeles and 1 urban kebele. TahtayAdyabo District is located about 405 kilometers from Mekelle and 95 kilometer from Shire-Endaslase Town, the capital of North Western Zone of Tigray Region. It is bounded by the District of LaelayAdyabo to the east, KaftaHumera and Eritrea to the west and, AsgedeTsimbla to the south and Eritrea to the north. Geographically, it is located between $37^{\circ} 21^{\prime} 13^{\prime \prime} \mathrm{E}$ to $38^{\circ} 10^{\prime} 33^{\prime \prime} \mathrm{E}$ longitude and $14^{\circ}$ 31 '34"N to $14^{0} 51^{\prime} 42 " \mathrm{~N}$ latitude [12].

The district has a total population of about 100,958, of which 50,924 and 50,034 are males and females respectively [1]. The district has area coverage of 253,655 hectare out of which 60,017 hectare is crop land, 42,778 hectare is covered by forest and the rest is homestead and wasteland. The district is divided into three major agroecological zones; hot to warm semi-arid low lands $(70 \%)$, hot to warm sub-moist low lands (11.25\%), and tepid to $\mathrm{cool}$ moist mid highlands (18.75\%). The average annual temperature of the district is $31^{\circ} \mathrm{C}$ and found at an elevation of 800-1500 masl[11].

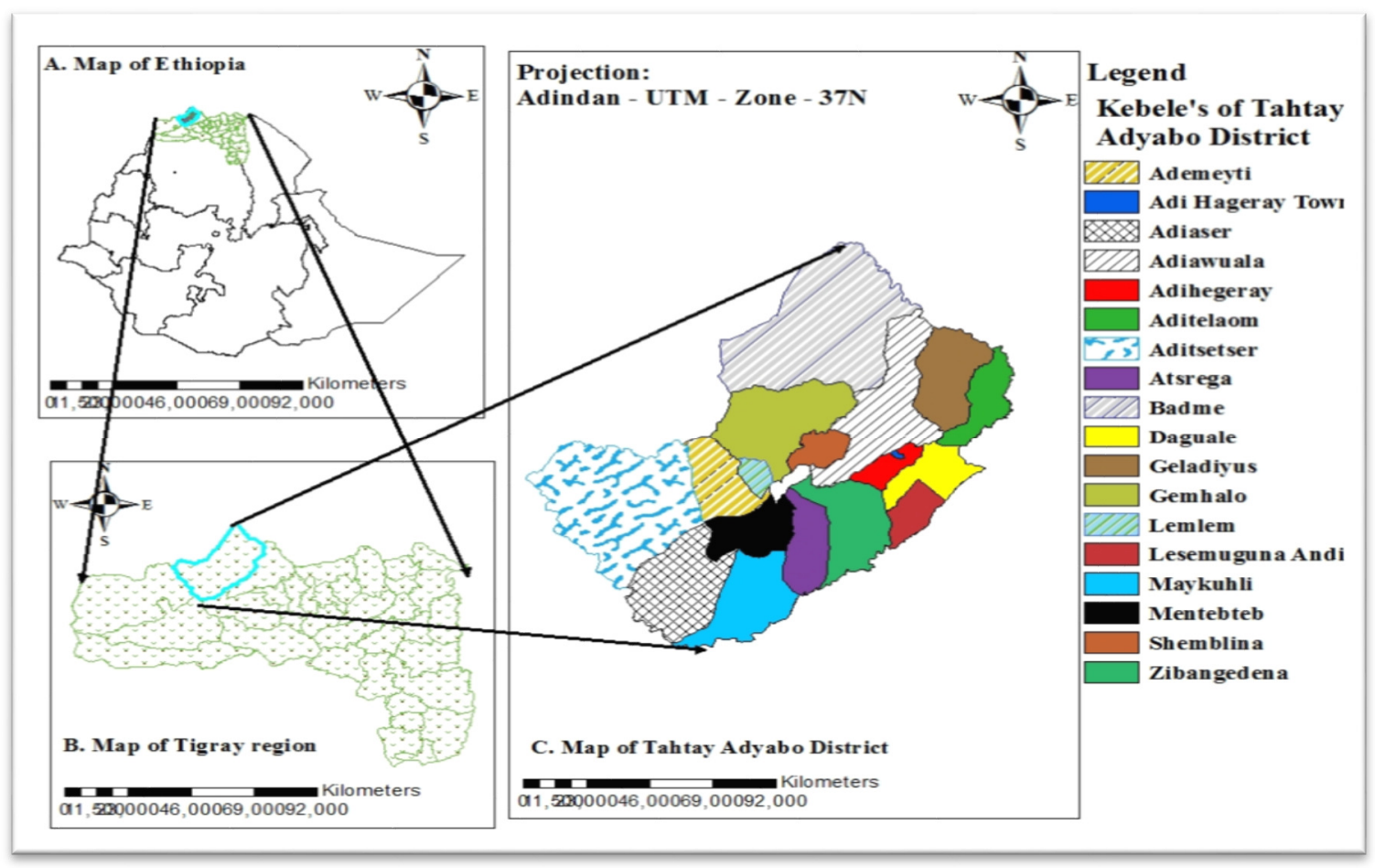

Figure 1: Map of TahtayAdyabo District

www.gjournals.org 


\section{Data types and sources}

The study used primary and secondary types of data. Primary data were collected using informal and formal surveys. The informal survey used key informants interview and visual observations. Specific checklists were used to guide key informants' interviews. The formal survey was undertaken through formal interviews with randomly selected farmers and traders using a pre-tested semi-structured questionnaire for each group. The secondary data were collected from Central Statistical Authority (CSA), Office of Agriculture and Rural Development (OARD), and other sources.

\section{Sampling procedure and sampling size}

Multi-stage random sampling technique was used to select representative small ruminant producer kebeles and sample households. In the first stage, out of 18 kebeles of the district 10 small ruminant producer kebeles were purposively selected based on the level of production. In the second stage, from the 10 small ruminant producer rural kebeles, four sample kebeles namely Adi-Aser, Gemhalo, Mentebteb and Zban-Gedena were selected randomly. In the third stage, a total of 138 sample households were selected randomly using probability proportional to population size-sampling technique based on [3]this formula:

$$
n=\frac{z^{2} p(1-p)}{e^{2}}
$$

Where,

$n$ is the sample size

$p$ is the estimated proportion of small ruminant producers from the total population

$z=1.96$ and $e=0.05$

Table 1: Sample size distribution in the sample kebeles

\begin{tabular}{lcc}
\hline Name of selected kebeles & $\begin{array}{c}\text { Total number of } \\
\text { small ruminant producers }\end{array}$ & $\begin{array}{c}\text { Number of } \\
\text { sample households }\end{array}$ \\
\hline Adi Aser & 328 & 30 \\
Gemhalo & 383 & 35 \\
Mentebteb & 292 & 27 \\
Zban Gedena & 494 & 46 \\
\hline Total & 1497 & 138 \\
\hline \multicolumn{3}{c}{}
\end{tabular}

For this study, data from traders were also collected. The sites for the trader surveys were market towns in which a good sample of small ruminant traders are available. A total of 6 large traders, 12 small traders and 8 collectors were randomly selected constituting a total of 26 traders from Sheraro, Tekeze, Adi- Hageray and Shmelba markets.

\section{Methods of data analysis}

A descriptive statistical method of data analysis was used for the use of percentages to examining and describing household and traders characteristics.

\section{RESULTS AND DISCUSSION}

\section{Opportunities in small ruminant production and marketing}

Availability of high performance of local breeds(Begait breed), increasing their price and demand for live small ruminant and meat in local markets due to a rising population and increase in income of consumers and their uses as source of income, manure, meat and milk for household consumption were some of the opportunities of small ruminant production by most of the producers. 
The district is endowed with diverse browse local herbs, shrubs and grazing lands which can be potential feed sources for small ruminant. Furthermore, provisions of infrastructure facilities like financial institutions are the infrastructural advantages that facilitate the production and marketing of small ruminant in the study area. There are also various organizations such as Dedebit Credit and Saving Institution, Save the Children and Shire-Mitsebri agricultural research center that provide production inputs and technical services to the farmers. Moreover, Tahtay Adyabo District has better market access to Shire-Endaslase and Humera towns which are the capital-city of north western and western zone.

\section{Constraints in small ruminant production and marketing}

There are factors that hinder the production of small ruminant in the study area. The majority of the sample producers indicated animal diseases, inadequate animal health services, shortage of feed, land, labor and predators as major constraints of small ruminant production. The major constraints of small ruminant production are discussed in Table 1.

Diseases and parasites are reported as the major constraints to small ruminant production by causing high mortality of small ruminant. Among the total sample of respondents, 58.7\% replied animal diseases as their production problem. This is caused mainly due to inadequate veterinary service delivery and shortage of drugs.

\begin{tabular}{|c|c|c|}
\hline \multirow[t]{2}{*}{ Production constraints } & \multicolumn{2}{|c|}{ Total sample( $\mathrm{N}=138)$} \\
\hline & $\mathrm{N}$ & $\%$ \\
\hline Animal diseases & 81 & 58.7 \\
\hline Inadequate animal health services & 18 & 13 \\
\hline Shortage of feed & 15 & 10.9 \\
\hline Shortage of land & 13 & 9.4 \\
\hline Shortage of labor & 7 & 5.1 \\
\hline Predators & 4 & 2.9 \\
\hline
\end{tabular}

$\mathrm{N}$ is number of respondents.

Source: Own computation from survey result, 2015

The drugs and veterinary services provided by Office of Agriculture and Rural Development of the district to small ruminants, such as treating illness, and vaccinations are not enough as compared with demand and high population of small ruminant. This inadequate veterinary services and drug supply was what caused high mortality of small ruminant and thereby low productivity. The major diseases and parasites of sheep and goats in the study area are Pasteurellosis, sheep and goat pox, anthrax, Brucella, Peste des Petits Ruminants (PPR), and Mange mites/skin diseases.

Small ruminant producers and traders also identified major constraints regarding small ruminant marketing in Tahtay Adyabo District. Lack of livestock market information, seasonality of small ruminant demand, distance to livestock market and low market price are some of the constraints in the study area. Among the total sample of respondents, $57.98 \%$ replied lack of livestock market information as their marketing problem (Table 2). Most producers get market information from their neighbors, who sold small ruminant a week earlier. Due to this, small ruminant producers depend on actual market day information or depend on previous market information for price decisions.

Table 2: Marketing constraints of small ruminant producers

\begin{tabular}{lcc}
\hline Marketing constraints & \multicolumn{2}{c}{ Total sample (N=138) } \\
\cline { 2 - 3 } & $\mathrm{N}$ & $\%$ \\
\hline Lack of livestock market information & 80 & 57.98 \\
Seasonality of small ruminant demand & 41 & 29.71 \\
Distance to livestock market & 14 & 10.14 \\
Low market price for small ruminant & 3 & 2.17 \\
\hline
\end{tabular}

$\mathrm{N}$ is number of respondents.

Source: Own computation from survey result, 2015 
Among the total sample of respondents, $29.71 \%$ replied seasonality of small ruminant demand as their marketing problem. Demand for small ruminant varies according to the seasons and fasting times. Since the majority of the population in the area follows Orthodox Christianity, demand for small ruminant varies with the fasting seasons. Demand is high during cultural and religious holydays, and during the two to three weeks before and after the Ethiopian New Year, Christmas and Easter. Thus, small ruminant producers are forced to sell their animals during these months to meet their cash needs. Demand for small ruminant declines during the fasting seasons, when the followers of Ethiopian Orthodox Christians do not consume any animal-based food.

The major small ruminant marketing constraints mentioned by traders are related with unlicensed (informal) traders, seasonality of supply and problem in information flow (Table 3). Among the total sample of traders, $61.5 \%$ replied unlicensed (informal) traders as their marketing problem. Most of the traders in the study area in small ruminant markets are informal operators who have no trade license.Formal business operators are discouraged since they have to compete with informal operators who do not pay tax.Among the total sample of traders, $27 \%$ replied seasonality of small ruminant supply as their marketing problem. Small ruminant supply increases during August, September, November and January, due to an improvement of body condition in small ruminant at this time, and an increase in demand linked to holidays such as Christmas and New Year. However, during April, May and June, farmers do not sell their small ruminants because the animals lose body weight due to feed shortages.

Table 3: Marketing problems mentioned by traders

\begin{tabular}{lcc}
\hline Marketing problems & \multicolumn{2}{c}{ Total sample $(\mathrm{N}=26)$} \\
\cline { 2 - 3 } & $\mathrm{N}$ & $\%$ \\
\hline Unlicensed traders & 16 & 61.5 \\
Seasonality of supply & 7 & 27 \\
Problem in information flow & 3 & 11.5 \\
\hline
\end{tabular}

$\mathrm{N}$ is number of respondents.

Source: Own computation from survey result, 2015

\section{CONCLUSION AND RECOMMENDATION}

One of the constraints hindering the development of small ruminant production were animal diseases andinadequate animal health services. Allocation of adequate budget for procurement of drugs and provision of regular vaccination and treatment for small ruminant is essential. Similarly, training at different levels in small ruminant disease prevention and control is also essential to increase the production of small ruminant. Shortage of feed and shortage of land were also constraints of small ruminant production in the study area. Integrating high yielding improved forage crops with soil and water conservation activities, training farmers in conservation of locally available feed sources and their efficient utilization and link forage development to soil and water conservation structures are essential interventions to increase the production and productivities of small ruminant. The major constraints identified by producers regarding small ruminant marketing were lack of livestock marketinformation, long distance to livestock markets and seasonality of small ruminant demand. Provision of timely and adequate market information, establishment of livestock markets with all necessary facilities and establishment of meat processing and export abattoirs around the area to create non seasonal demand that can also encourage small ruminant producers to supply animals regardless of seasons are important interventions. Seasonality of small ruminant supply during feed shortages and unlicensed traders were also constraints mentioned by traders regarding small ruminant marketing. Creation of awareness to farmers about improved forage species and supplementary feeding and enforced government rules and regulations on business registration and licensing are important interventions.

\section{ACKNOWLEDGMENT}

Thanks to Tahtay Adyabo district Office of Agriculture and rural development staff members, development agents and farmers for their contribution to the accomplishment of this study. 


\section{REFERENCES}

1. CSA (Central Statistical Agency) (2015).Population Projection of Ethiopia for All Regions.At District Level from 2014 - 2017, Addis Ababa, Ethiopia.

2. CSA (Central Statistical Agency) (2015). Agricultural Sample Survey, 2014/15 (2007 E.C.), Volume II: Report on Livestock and livestock characteristics (Private peasant holdings). Statistical Bulletin 578, Addis Ababa, Ethiopia.

3. Cochran, W.G(1977). Sampling techniques, $3^{\text {rd }}$ Edition. John Wiley \&Sons, New York.

4. Endeshaw A (2007). Assessment on production system and marketing of goats at Dale District, Sidama Zone. MSc Thesis. Hawassa University, Awassa, Ethiopia.

5. Gebremariam S, Amare S, Baker D and Solomon A (2010). Diagnostic study of live cattle and beef production and marketing: Constraints and opportunities for enhancing the system; Consultant to International Food Policy Research Institute: ILRI.6.

6. Gebremedhin B, Hoekstra D and Jemaneh S (2007). Heading towards commercialization? The case of live animal marketing in Ethiopia.Improving Productivity and Market Success (IPMS) of Ethiopian Farmers Project Working Paper 5. ILRI (International Livestock Research Institute), Nairobi, Kenya.

7. Getahun L(2008). Productive and economic performance of small ruminant production in production system of the highlands of Ethiopia.Doctoral Dissertation, University of Hohenheim, Hoheinheim, Germany.

8. Gizaw S, Tegegne A, Gebremedhin B and Hoekstra D(2010). Sheep and goat production and marketing systems in Ethiopia:Characteristics and strategies for improvement. IPMS (Improving Productivity and Market Success) of Ethiopian Farmers Project Working Paper 23, Nairobi, Kenya.

9. Hussen $M$, Kechero $Y$ and Molla $M(2015)$.Productive and reproductive performances ofruminant livestock in Jimma Zone, Southwest Ethiopia. Journal of Reproduction and Infertility, 6 (2): 27-34.

10. Legese G, Haile A, Duncan A, Dessie T, Gizaw S and Rischkowsky B (2014).Sheep and goat value chains in Ethiopia: A synthesis of opportunities and constraints. ICARDA/ILRI Project Report, Nairobi, Kenya.

11. TADOoARD (Tahtay Adyabo District Office of Agriculture and Rural Development)(2015). Annual report, Sheraro, Ethiopia.

12. TADOol (Tahtay Adyabo District Office of Information)(2015). Annual report, Sheraro, Ethiopia

13. Tesfay Z, Anal Ak and Gebreyohanis G (2012). Assessment of the sheep production system of northern Ethiopia in relation to sustainable productivity and sheep meat quality. International Journal of Advanced Biological Research, 2(2): 302-313.

14. Tibbo $M(2006)$. Productivity and health of indigenous sheep breeds and crossbreds in the central Ethiopian highlands.Doctoral Dissertation, Swedish University of Agricultural Sciences, Uppsala, Sweden.

15. Tsedeke K(2007). Production and marketing of sheep and goats in Alaba District, Southern Nations Nationalities and Peoples Region.M.S thesis, Hawassa University, Hawassa, Ethiopia.

Cite this Article: Desta Z (2017). Assessment of Opportunities and Constraints of Small Ruminant Production and Marketing in Tahtay Adyabo District, Tigray, Ethiopia. Greener Journal of Social Sciences, 7(1): 001-006, http://doi.org/10.15580/GJSS.2017.1.010917002 